\title{
KAJIAN JENIS - JENIS BURUNG DI DESA NGADAS SEBAGAI DASAR PERENCANAAN JALUR PENGAMATAN BURUNG (Birdwatching)
}

\author{
Kristin Widyasari $^{1}$, Luchman Hakim ${ }^{2}$, Bagyo Yanuwiadi ${ }^{2}$ \\ ${ }^{1}$ Mahasiswa Jurusan Biologi, Fakultas Matematika dan ilmu pengetahuan Alam, Universitas Brawijaya \\ 2Jurusan Biologi, Fakultas Matematika dan ilmu pengetahuan Alam, Universitas Brawijaya
}

\begin{abstract}
Abstrak
Penelitian ini dilakukan dengan tujuan untuk mengetahui jenis-jenis serta sebaran spasial burung-burung yang ada di desa Ngadas. Penelitian ini dilaksanakan pada bulan Agustus 2010- Maret 2011 di Desa Ngadas, Kecamatan Poncokusumo, Kabupaten Malang. Pengamatan burung dilakukan dengan menjelajahi jalur pengamatan yang telah ditentukan sebelumnya. Daerah yang dijadikan lokasi pengamatan adalah hutan disekitar Desa Ngadas, wilayah lahan yang diolah serta daerah pemukiman. Data yang diambil dalam pengamatan burung tersebut meliputi data jenis burung, jenis vegetasi dimana burung dijumpai serta posisi koordinat dan lokasi perjumpaan dengan burung. Data mengenai jenis dan jumlah burung pada masing-masing karakter lahan ditabulasikan dengan menggunakan Microsoft Excel 2007, untuk selanjutnya dibuat diagram yang menunjukkan perbandingan antara jenis burung yang ditemukan pada masing-masing karakter lahan. Sementara untuk posisi koordinat burung tersebut dijumpai ditabulasikan dengan menggunakan Microsoft Access 2007, yang selanjutnya akan diolah dengan menggunakan software ArcGIS 9.3 untuk dibuat peta sebaran burung Desa Ngadas. Berdasarkan pengamatan yang dilakukan di Desa Ngadas, diketahui bahwa setidaknya ada 13 famili dan 23 spesies burung yang ada di Desa Ngadas. Ketiga belas famili burung ini tersebar di seluruh wilayah desa Ngadas, namun jumlah famili paling banyak ditemukan di wilayah hutan sekunder, kemudian diikuti oleh wilayah ladang serta daerah pemukiman. Dengan melihat keragaman burung serta distribusinya di Desa Ngadas, perencanaan kegiatan Birdwatching memiliki potensi besar untuk dilaksanakan sebagai salah satu upaya konservasi dan pengenalan akan pentingnya melestarikan dan menjaga keberadaan burung.
\end{abstract}

Kata kunci: birdwatching, desa Ngadas, sebaran

\section{Abstract}

The purposes of this research were to know bird species and its distributions in Ngadas village, malang Regency. Research was done at August 2010 to March 2011. The Bird's observation was done by exploring the areas which were determined before, it was settlement area, agricultural field and also secondary forest area. The data which were collected in this research include birds species, vegetation in the area where the birds was found, and the coordinate position of bird which was found. Data about species and number of birds in each area will tabulated using Microsoft Excel 2007, the data about coordinate position of bird, was tabulated using Microsoft Access 2007, and proceed using software ArcGIS 9.3 to produce the map of bird distribution in Ngadas. Based on the, there were 13 family of bird and 23 species which found in three type of areas. Those 13 family were sdistributed in all around area in Ngadas. The most area with highest number of bird family was in secondary forest area, followed by agricultural field. The fewest area was settlement area. From the output which showing the number of birds and their diversity, we can conclude a design of Birdwatching in Ngadas.

Keywords: Bird, birdwatching, Ngadas, distribution

\section{PENDAHULUAN}

Burung merupakan kelompok hewan dari kelas Aves yang memiliki beberapa karakteristik yang membedakannya dari kelaskelas yang lainnya. Kebanyakan burung hidup diurnal, meskipun demikian, ada pula burungburung yang nocturnal. Banyak burung dikenali dari kemampuannya terbang, meskipun ada

\footnotetext{
Alamat korespondensi:

Kristin Widyasari

Email : kristinwidyasari@gmail.com

Alamat : Hoegidong Cheonjangsanro-9- ga gil nomor 3. Seoul
}

beberapa spesies yang tidak memiliki kemampuan tersebut. Burung tersebar hampir di seluruh daerah di muka bumi. Di seluruh kawasan Jawa, jumlah total dari jenis burung yang tercatat adalah 494 jenis yang mewakili setengah dari suku burung di dunia. Sebanyak 24 jenis merupakan endemik Jawa, 16 jenis terbatas di Jawa, 1 jenis terdapat di Bali dan 7 jenis terdapat di kedua pulau tersebut, 366 diantaranya adalah jenis penetap dan 128 lainnya sebagai pengunjung / pengembara (migran) [6]. Keberadaan burung-burung di suatu tempat sangat dipengaruhi oleh ketersediaan makan, vegetasi serta aktivitas manusia [7]. 
Sebagai salah satu kawasan yang dilindungi, Taman Nasional Bromo Tengger Semeru (TNBTS) memiliki keanekaragaman vegetasi yang memungkinkan tersedianya habitat yang sesuai bagi berbagai jenis burung. Sebagai salah satu desa yang berada dalam kawasan TNBTS, desa Ngadas memiliki peranan dalam dinamika keberadaan burung-burung yang ada di kawasan TNBTS. Hal ini terutama disebabkan semakin banyaknya penduduk desa Ngadas yang melakukan praktek pembukaan hutan untuk dijadikan daerah pertanian, meskipun saat ini praktek tersebut sudah dilarang oleh pemerintah. Keberadaan lahan pertanian yang menggantikan fungsi hutan tersebut tidak diragukan lagi menyebabkan beberapa jenis burung yang bergantung terhadap keberadaan vegetasi hutan kehilangan habitat aslinya [2].

Dalam rangka untuk mengatasi masalah tersebut, diperlukan suatu pemecahan yang bisa memberikan keuntungan, baik dari segi konservasi terhadap jenis-jenis burung yang ada di kawasan TNBTS, maupun bagi masyarakat desa Ngadas yang tinggal di kawasan tersebut. Salah satu cara yang bisa dilakukan adalah dengan mengarahkan Desa Ngadas sebagai salah satu daerah tujuan wisata alam Birdwatching.

Birdwatching merupakan salah satu kegiatan pengamatan burung di alam. Kegiatan wisata alam Birdwatching ini, di satu sisi bisa memberikan manfaat ekonomi bagi masyarakat sekitar karena banyaknya wisatawan yang akan melakukan kunjungan ke daerah tersebut, di sisi lain juga bisa memberikan manfaat konservasi bagi jenis-jenis burung yang ada di kawasan TNBTS. Namun, yang menjadi kendala saat ini adalah kurang tersedianya informasi tentang distribusi spasial burung yang ada di Desa Ngadas. Keberadaan informasi ini akan sangat membantu terlaksananya kegiatan wisata Birdwatching serta untuk mempermudah proses konservasi terhadap burung-burung yang ada di kawasan tersebut. Oleh karena itu penelitian ini penting untuk dilaksanakan agar informasi mengenai sebaran spasial burung-burung yang ada di Desa Ngadas bisa terpenuhi dengan pembuatan peta sebaran spasial burung-burung yang ada di Desa Ngadas menggunakan aplikasi Sistem Informasi Geografis, sehingga peta sebaran bisa digunakan sebagai gambaran rancangan pembuatan jalur untuk pengamatan burung (Birdwatching) di Desa Ngadas.

\section{METODE PENELITIAN \\ Waktu Dan Tempat}

Penelitian dan pengolahan data dilakukan pada bulan September 2010 - Maret 2011. Penelitian lapang dilaksanakan di Desa Ngadas Kecamatan Poncokusumo, Kabupaten Malang. Sedangkan pengolahan data dilakukan di Laboratorium Biokomputasi dan Informatika, Jurusan Biologi, Fakultas Matematika dan IImu Pengetahuan Alam, Universitas Brawijaya, Malang.

\section{Deskripsi Area Studi}

Penelitian dilakukan di Desa Ngadas yang terletak di koordinat $112^{\circ} 53^{\prime} 50^{\prime \prime}$ BT$112^{\circ} 5^{\prime} 10^{\prime \prime} \mathrm{BT}$ dan $07^{\circ} 59^{\prime} 40^{\prime \prime}$ LS - 07 $58^{\prime} 20^{\prime \prime}$ LS [5]. Secara administratif Desa Ngadas masuk ke dalam wilayah Kecamatan Poncokusumo, Kabupaten Malang. Desa Ngadas termasuk ke dalam kawasan Taman Nasional Bromo Tengger Semeru (TNBTS), dengan keadaan topografi bergelombang dengan lereng yang landai sampai berbukit dengan derajat kemiringan yang tegak. Dalam penelitian ini, lokasi yang diamati meliputi daerah pemukiman, ladang dan hutan yang membatasi Desa Ngadas dengan wilayah TNBTS. Berdasarkan tipe vegetasinya, desa Ngadas dibedakan menjadi 4 tipe ekosistem, diantaranya ekosistem hutan sekunder, Ladang dan daerah pemukiman.

\section{Teknik Pengamatan Burung}

Pengamatan burung dilakukan secara jelajah pada jalur pengamatan yang telah ditentukan sebelumnya. Daerah yang dijadikan lokasi pengamatan adalah hutan disekitar Desa Ngadas, wilayah lahan yang diolah dan daerah pemukiman. Daerah-daerah ini diambil karena dianggap mewakili 3 tipe ekosistem yang ada di desa Ngadas. Pengamatan dilakukan pada tiga pembagian waktu, dimana waktu pertama dimulai pukul 06.00-09.00 (pengamatan pagi), kemudian pukul 10.00-13.00 (pengamatan siang), serta pengamatan sore 13.00-17.00. Dalam proses pengambilan data ini dilakukan pengulangan sebanyak 5 kali. Berikut merupakan peta jalur pengamatan yang diambil: 


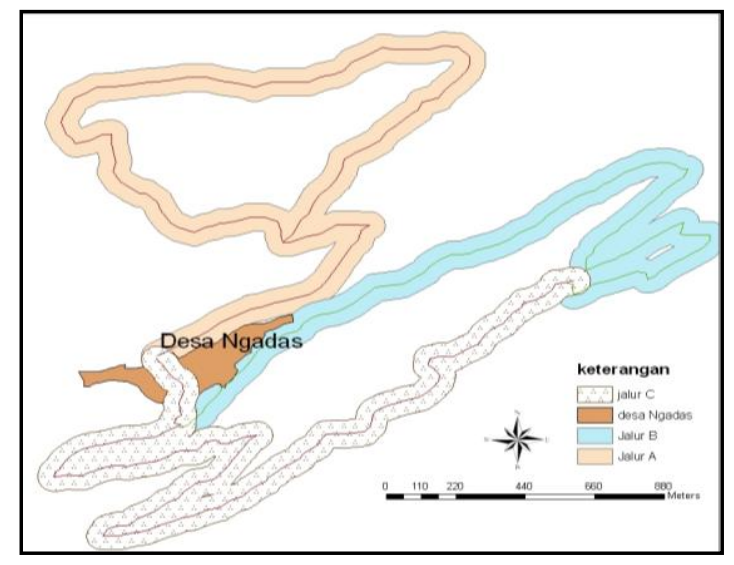

Gambar 1. Jalur Pengamatan Burung di Desa Ngadas

Pengamatan burung dilakukan dengan menggunakan bantuan binokuler dengan lensa $10 \times 50 \mathrm{~mm}$. Selanjutnya burung yang diperoleh dideskripsikan secara morfologis dan diidentifikasi dengan menggunakan Buku Panduan Lapangan Pengenalan Burung-Burung, antara lain Panduan Lapangan Burung-Burung di Sumatera, Jawa, Bali dan Kalimantan (McKinnon, 1992), A Photographic Guide to The Birds of Indonesia (Strange, 2001). Identifikasi dilakukan hingga tingkat spesies jika memungkinkan. Selain itu, dalam pengamatan yang dilakukan, jumlah burung yang ditemukan dihitung jumlahnya serta difoto jika memungkinkan. Lokasi dimana burung- burung tersebut ditemukan selanjutnya dicatat posisi koordinatnya dengan menggunakan bantuan GPS (MAP 60CSx GARMIN). Pengamatan dilakukan di sepanjang jalur yang telah ditentukan pada radius \pm 10 - 100 meter sisi kiri dan kanan jalur pengamatan. Pengamatan juga dilakukan terhadap tipe vegetasi yang tumbuh di sekitar burung dijumpai, vegetasi tersebut dicatat jenis serta habitusnya.

\section{Analisis Data}

Proses analisis yang dilakukan dalam penelitian ini adalah dengan melakukan analisis statistik deskriptif, dimana data-data yang diperoleh dikelompokkan berdasarkan kepentingannya masing-masing. Data mengenai jenis burung, jumlah burung dan tipe vegetasi dalam masing-masing habitat ditabulasikan dengan menggunakan Microsoft Excel 2007, untuk selanjutnya dibuat diagram yang menunjukkan perbandingan antara jenis burung yang ditemukan pada masing-masing habitat, serta untuk mengetahui dominansi dari jenisjenis burung yang ditemui pada masing-masing habitat tersebut. Sementara untuk data mengenai ketinggian tempat dan sebaran burung yang diperoleh berdasarkan posisi koordinat burung tersebut dijumpai, ditabulasikan dengan menggunakan Microsoft Access 2007, yang selanjutnya akan diolah dengan menggunakan software ArcGIS 9.3 untuk dibuat peta sebaran burung-burung yang ada di Desa Ngadas. Berdasarkan output yang diperoleh dari masingmasing proses pengolahan, selanjutnya dilakukan analisis secara deskriptif sehingga bisa ditarik kesimpulan mengenai jenis-jenis burung yang ada di Desa Ngadas beserta persebarannya.

\section{HASIL DAN PEMBAHASAN}

\section{Famili Burung yang Ada di Desa Ngadas}

Desa Ngadas memiliki keanekaragaman jenis burung yang bisa lebih dioptimalkan dalam kegiatan Birdwatching. Jenis-jenis burung tersebut ditemukan pada 3 karakter lahan yang ada di desa Ngadas yakni wilayah pemukiman, ladang serta hutan sekunder. Jenis vegetasi yang banyak terdapat pada masing-masing karakter lahan tersebut juga berbeda.

Keberadaan jenis-jenis vegetasi tersebut beserta faktor-faktor lainnya baik biotik maupun abiotik pada masing-masing karakter lahan di Desa Ngadas secara fungsional akan memberikan dukungan bagi keberadaan burung berupa ketersediaan pakan, air, tempat berlindung dari panas dan pemangsa serta tempat untuk bersarang, beristirahat dan memelihara anaknya.

Berdasarkan pengamatan yang telah dilakukan diperoleh beberapa famili yang diketahui berada di wilayah Desa Ngadas antara lain Turnicidae, Motacilidae, Apopidae, Piccidae, Passeridae, Pycnononidae, Nectaridae, Zosteropidae, Accipitridae, Sylviidae, Phasianidae, dan Columbidae.

Turnicidae merupakan suku burung yang memiliki ukuran yang kecil, berekor pendek dan umumnya bertubuh gempal. Sekilas menyerupai burung puyuh dari suku Phasianidae, namun tidak memiliki jari belakang [6].

Motacilidae merupakan kelompok suku yang cukup besar dan tersebar luas. Terdiri dari burung darat yang bertubuh ramping dan berjalan dengan anggun. Kebanyakan pipit yang merupakan salah satu jenis dari suku ini secara sepintas mirip dengan brajangan, namun memiliki ciri khas tungkai lebih panjang dan paruh lebih ramping [6].

Apopidae merupakan suku burung pemakan serangga. Memiliki kemampuan terbang yang cepat dan tersebar di seluruh dunia. Memiliki ciri khas sayap panjang dan runcing, menunjuk ke belakang saat terbang, ekor pendek atau persegi 
atau panjang menajam, kaki sangat kecil, jarang bertengger di pohon, biasanya beristirahat di pohon, karang, atau tembok dengan menggukan kukunya yang tajam [6].

Picidae merupakan suku dengan beranggotakan banyak jenis burung dan dikenal baik. Memiliki ukuran tubuh sedang dengan paruh yang panjang dan kuat untuk melubangi kayu. Semua jenis menggunakan batang dan cabang pohon sebagai tempat untuk mencari makan. Terbang dengan gerakan membungkuk yang tidak tetap, dan bersuara keras tidak selaras [6].

\section{Sebaran Spasial dan Temporal Burung Desa Ngadas}

\subsection{Distribusi Spasial Burung di Desa Ngadas}

Berdasarkan penelitian yang telah dilakukan pada 3 jalur pengamatan dengan ulangan data sebanyak 5 kali, diperoleh 592 individu yang terbagi atas 23 species dan 13 famili. Jumlah dan nama famili burung-burung di Desa Ngadas berdasarkan pembagian daerah pengamatan dapat dilihat pada gambar 2 .

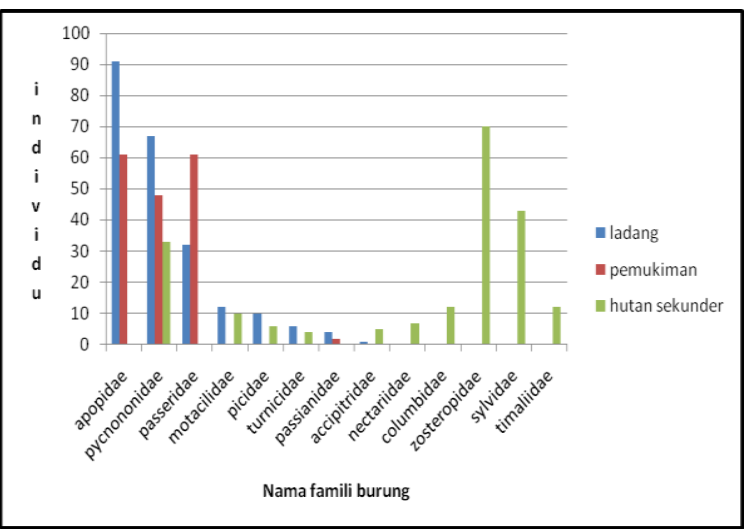

Gambar 2. Jumlah Burung yang Ditemukan di Desa Ngadas Berdasarkan Lokasi Pengamatan

Sementara nama family, nama spesies serta nama lokal dari burung-burung yang ada di Desa Ngadas bisa dilihat pada tabel 1 . Keberadaan burung di Desa Ngadas dipengaruhi oleh beberapa faktor, terutama akibat aktivitas manusia. Fragmentasi habitat, degradasi serta rusaknya habitat menyebabkan semakin berkurangnya keberadaan burung-burung di habitat aslinya [3]. Keberhasilan burung untuk hidup di suatu habitat sangat ditentukan oleh keberhasilannya dalam memilih dan menciptakan habitat yang sesuai baginya [8].

Persebaran burung berdasarkan lokasi pengamatan menunjukkan hasil dimana diversitas burung lebih banyak berada pada lokasi hutan sekunder, diikuti daerah ladang kemudian pemukiman. Perbedaan diversitas burung yang ditemukan pada masing-masing lokasi pengamatan terutama disebabkan oleh ketersediaan pangan, aktivitas, waktu pengamatan serta kondisi habitat tersebut. Odum (1994) menjelaskan bahwa, tingkat ketersediaan makan bagi burung menyebabkan perbedaan keanekaragaman jenis burung yang ada pada suatu habitat.

Tabel 1. Nama Latin, nama lokal dan famili burung

\begin{tabular}{|c|c|c|c|}
\hline No & Nama Famili & Nama Spesies & Nama Lokal \\
\hline \multirow{2}{*}{1.} & \multirow{2}{*}{ Accipitridae } & $\begin{array}{l}\text { Ictinaetus } \\
\text { malaynensis }\end{array}$ & Elang Hitam \\
\hline & & $\begin{array}{l}\text { Spizaetus } \\
\text { bartelsi }\end{array}$ & Elang Jawa \\
\hline \multirow{2}{*}{2.} & \multirow{2}{*}{ Phasianidae } & $\begin{array}{l}\text { Melanoperdix } \\
\text { nigra }\end{array}$ & $\begin{array}{l}\text { Puyuh } \\
\text { hitam }\end{array}$ \\
\hline & & gallus gallus & $\begin{array}{l}\text { Ayam hutan } \\
\text { merah }\end{array}$ \\
\hline \multirow{2}{*}{3.} & \multirow{2}{*}{ Turnicidae } & Turnix sy/vatica & $\begin{array}{l}\text { Gemak } \\
\text { tegalan }\end{array}$ \\
\hline & & Turnix suscitator & $\begin{array}{l}\text { Gemak } \\
\text { loreng }\end{array}$ \\
\hline \multirow{3}{*}{4.} & \multirow{3}{*}{ Collumbidae } & $\begin{array}{l}\text { Ducula } \\
\text { lacernulata }\end{array}$ & $\begin{array}{l}\text { Pergam } \\
\text { punggung } \\
\text { hitam }\end{array}$ \\
\hline & & Collumba livia & $\begin{array}{l}\text { Merpati } \\
\text { batu }\end{array}$ \\
\hline & & Geopelia striata & $\begin{array}{l}\text { Perkutut } \\
\text { jawa }\end{array}$ \\
\hline 5. & Appopidae & $\begin{array}{l}\text { Collocalia } \\
\text { vukanorum }\end{array}$ & $\begin{array}{l}\text { Walet } \\
\text { gunung }\end{array}$ \\
\hline \multirow{2}{*}{6.} & \multirow{2}{*}{ Piccidae } & $\begin{array}{l}\text { Picoides } \\
\text { mollucensis }\end{array}$ & Pelatuk besi \\
\hline & & $\begin{array}{l}\text { Dinopium } \\
\text { Javanense }\end{array}$ & Pelatuk lurik \\
\hline \multirow{2}{*}{7.} & \multirow{2}{*}{ Pycnononidae } & $\begin{array}{l}\text { Picnonotus } \\
\text { aurigaster }\end{array}$ & $\begin{array}{l}\text { Cucak } \\
\text { kutilang }\end{array}$ \\
\hline & & $\begin{array}{l}\text { Picnonotus } \\
\text { goiavier }\end{array}$ & $\begin{array}{l}\text { Merbah } \\
\text { cerukcuk }\end{array}$ \\
\hline \multirow[t]{2}{*}{8.} & \multirow[t]{2}{*}{ Sylviidae } & $\begin{array}{l}\text { Phylloscopus } \\
\text { borealis }\end{array}$ & Cikrak \\
\hline & & Cisticola exilis & Cici merah \\
\hline 9. & Nectariidae & $\begin{array}{l}\text { Aethopygia } \\
\text { eximia }\end{array}$ & $\begin{array}{l}\text { Burung } \\
\text { madu } \\
\text { gunung }\end{array}$ \\
\hline \multirow{3}{*}{10.} & \multirow{3}{*}{ Zosteropidae } & $\begin{array}{l}\text { Zosterps } \\
\text { palpebrosus }\end{array}$ & $\begin{array}{l}\text { Kacamata } \\
\text { biasa }\end{array}$ \\
\hline & & Zosterops flavus & $\begin{array}{l}\text { Kacamata } \\
\text { jawa }\end{array}$ \\
\hline & & $\begin{array}{l}\text { Zosterops } \\
\text { everitti }\end{array}$ & $\begin{array}{l}\text { Kacamata } \\
\text { belukar }\end{array}$ \\
\hline 11. & Timaliidae & $\begin{array}{l}\text { Malacopteron } \\
\text { cinereum }\end{array}$ & Asi topi sisik \\
\hline 12. & Motacilidae & $\begin{array}{l}\text { Anthus } \\
\text { novaeseelandiae }\end{array}$ & $\begin{array}{l}\text { Apung } \\
\text { tanah }\end{array}$ \\
\hline 13. & Ploceidae & Passer montanus & $\begin{array}{l}\text { Burung } \\
\text { gereja }\end{array}$ \\
\hline
\end{tabular}


Burung yang ditemukan di Desa Ngadas tersebar di hampir semua tempat, baik wilayah pemukiman, ladang, maupun hutan sekunder. Jika dilihat dari pola penyebarannya dan jenis family yang terdapat di wilayah-wilayah tersebut terlihat bahwa daerah hutan sekunder memiliki jenis family yang lebih banyak dibandingkan dengan wilayah lain, meski jumlah perjumpaannya tidak sebanyak di wilayah ladang. Penyebaran ini diperkirakan sangat dipengaruhi oleh ketersediaan makanan serta tempat hidup bagi jenis-jens family burung tersebut.

\subsection{Distribusi Temporal Burung di Desa Ngadas}

Dari 13 famili burung yang ditemukan, sebanyak 12 famili ditemukan aktif di pagi hari. Umumnya burung lebih banyak melakukan kegiatan di pagi hari. Hal ini disebabkan oleh beberapa faktor diantaranya pada pagi hari kondisi angin relatif lebih lemah. Menurut Dahlan, dkk (2009), aktivitas burung dalam mencari makan lebih banyak dilakukan pada pagi hari, antar pukul 05.00 sampai pukul 09.00 dan pada sore hari pada pukul 15.00 sampai dengan 18.00 bersamaan dengan perubahan cahaya matahari dan pergantian menjadi malam hari yang merupakan waktu bagi burung untuk pulang ke sarang dan melanjutkan aktivitas untuk esok hari, sedangkan pada siang hari lebih banyak digunakan untuk bertengger dan berlindung di pohon-pohon karena cuaca yang panas dan banyak terdapat aktivitas manusia, seperti kegiatan pertanian, pencarian kayu bakar atau rumput, dan lain-lain [4]. Menurut Balen (1999) keberadaan aktivitas manusia di sekitar habitat burung senantiasa disinyalir sebagai penyebab utama terhadap timbulnya gangguan terhadap keberadaan burung [1].
Dengan mengetahui pola distribusi temporal dari jenis-jenis burung di Desa Ngadas bisa diperoleh gambaran tentang kegiatan Birdwatching yang akan dilakukan. Informasi berkaitan dengan sebaran temporal dari jenisjenis burung di Desa Ngadas bisa dijadikan pedoman kapan waktu pengamatan yang paling sesuai dan menguntungkan dalam pengamatan burung (Birdwatching), sehingga dalam kegiatan Birdwatching pengamat memiliki kesempatan yang lebih besar untuk mengamati jenis-jenis burung yang ingin diamati.

Berdasar pola sebaran temporal dari burung di Desa Ngadas tersebut dapat dilihat bahwa burung lebih banyak melakukan aktivitas pada pagi hari, sehingga disarankan kegiatan Birdwatching dilakukan pada pagi hari, dengan waktu pengamatan antara pukul 06.00-10.00, seperti waktu pengamatan yang dilakukan oleh peneliti. Pada waktu-waktu tersebut burungburung lebih aktif bergerak, dan mencari mangsa sehingga frekuensi dan peluang perjumpaan dengan jenis-jenis burung tersebut lebih besar. Selain di pagi hari, pengamatan pada sore hari dimana burung-burung hendak kembali ke sarangnya juga bisa dijadikan alternatif pelaksanaan kegiatan Birdwatching ini.

\subsection{Perencanaan Jalur Pengamatan Burung dan} Wilayah Konservasi

Perencanaan yang matang mengenai jalur pengamatan, waktu dan lokasi yang digunakan dalam kegiatan birdwatching akan sangat membantu terlaksananya kegiatan ini. Dengan memperhatikan hal-hal tersebut dengan seksama kegiatan birswatching yang dilakukan bisa membawa keuntungan bagi pelaksana, pengamat maupun bagi masyarakat sekitar.

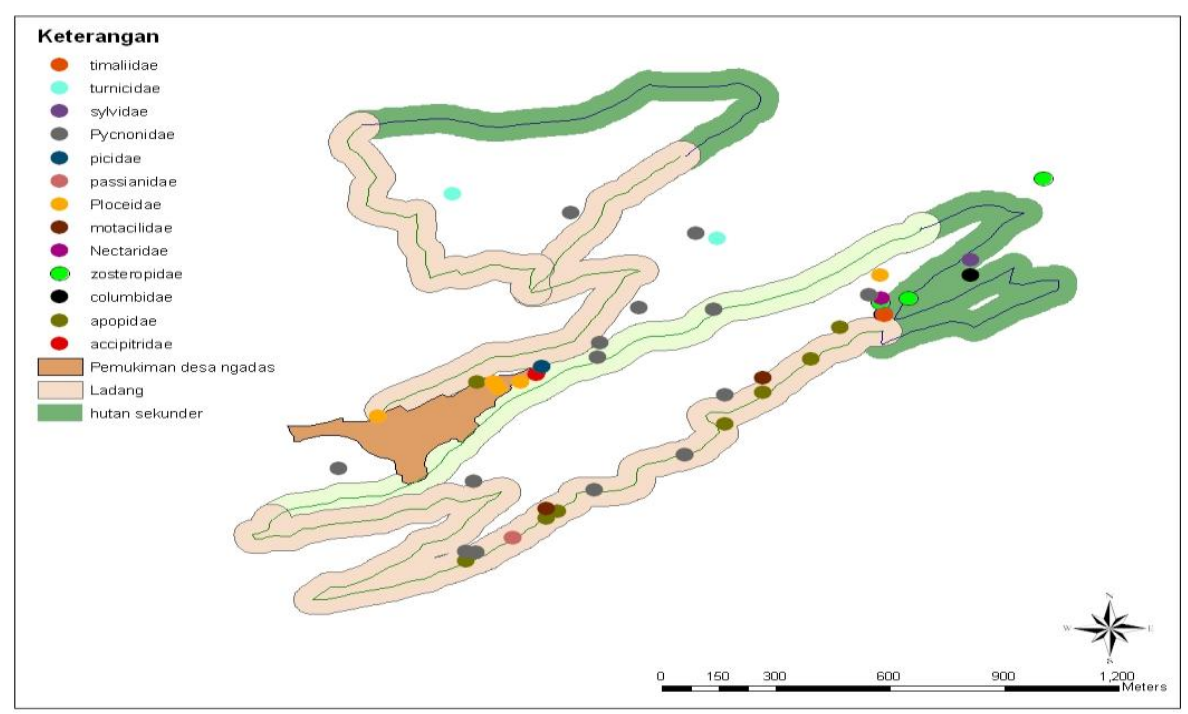

Gambar 4. Peta Distribusi Burung di Desa Ngadas 


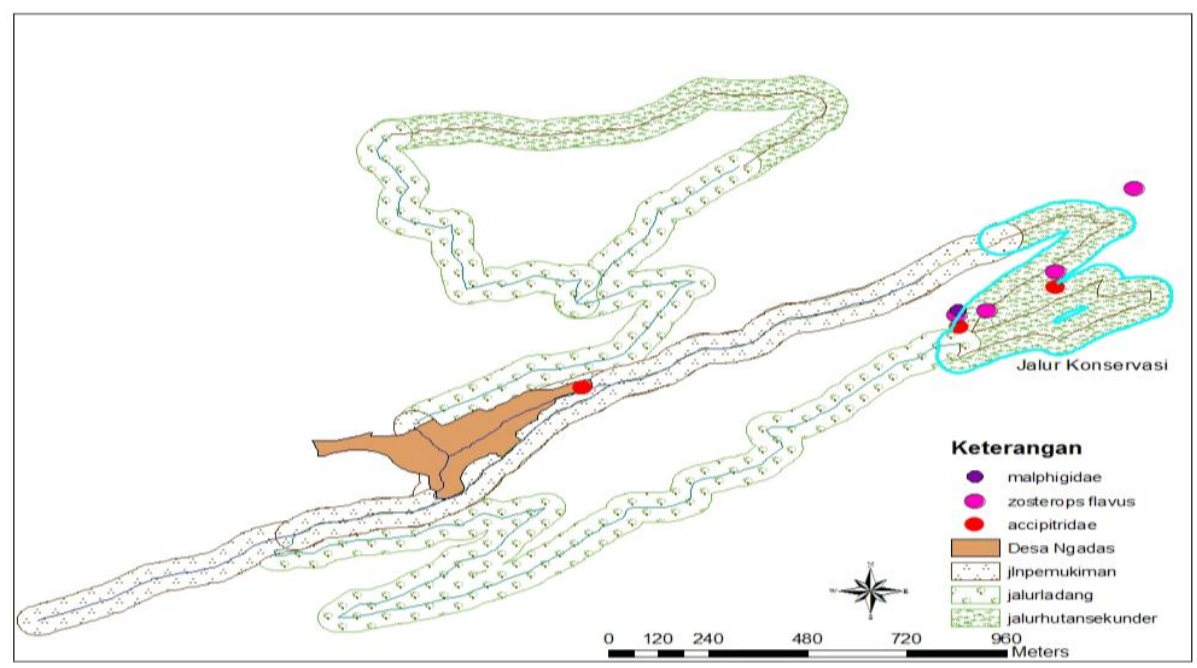

Gambar 5. Peta Jalur pengamatan dan Zona konservasi di desa Ngadas

Dengan demikian upaya untuk melaksanakan upaya konservasi burung melalui kegiatan birdwatching yang juga bisa memberikan nilai tambah bagi ekonomi masyarakat sekitar bisa terlaksana.

Pepohonan yang banyak terdapat di jalur konservasi antara lain Danglu (Engelhardia spicata), Cemara gunung (Casuarina junguniana), Mentigi (Vaccinum Sp.), Kemlandingan (Albizia lophanta), Akasia (Eucaliptus), serta jambu wer (Prunus persica). Jalur konservasi yang berada di hutan sekunder dalam kawasan Taman Nasional Bromo Tengger Semeru tersebut dipilih pada lokasi yang letaknya tidak terlalu jauh dari kawasan desa Ngadas dengan pertimbangan untuk menjaga jumlah serta jenis burung yang berada dalam kawasan desa Ngadas dengan menyediakan tempat untuk berkembang biak. Selain itu pertimbangan lain yang diambil adalah bahwa pada daerah tersebut dijumpai burungburung dengan status NT (Near Threatened) atau jenis burung yang berada dalam kategori terancam mendekati kepunahan yakni Zosterops flavus atau dikenal juga dengan nama burung kacamata jawa. Serta burung yang berada dalam kondisi terancam punah (EN) yakni elang jawa atau Spizaetus bartelsi. Keberadaan burungburung ini menjadi salah satu dasar pembuatan zona konservasi di jalur hutan sekunder. Dengan adanya jalur konservasi ini, maka pengamatan burung yang dilakukan di jalur ini harus dilakukan dengan aturan yang lebih ketat. Jalur Konservasi pada Gambar 5 ditandai dengan garis biru muda yang mengelilingi jalur pengamatan.

Dengan adanya aktivitas ekowisata Birdwatching ini diharapkan dapat memberikan penambahan ilmu pengetahuan, pengalaman, informasi, dan keterampilan bagi wisatawan.
Selain itu, memberi keuntungan masyarakat lokal dalam peningkatan kesejahteraan mereka. Hal ini dilakukan dengan melibatkan mereka dalam kegiatan wisata, misal sebagai pemandu wisata, pengelola (fasilitas wisata), fasilitator, atau maereka dijadikan objek/atraksi dari wisata yang akan dihadirkan tersebut.

\section{KESIMPULAN DAN SARAN Kesimpulan}

Desa Ngadas memiliki setidaknya 13 famili dan 23 spesies burung. Spesies-spesies tersebut diantaranya adalah Ictinaetus malaynensis dan Spizaetus bartelsi yang merupakan anggota dari Famili Accipitridae, Melanoperdix nigra dan gallus gallus dari Famili Phasianidae, Turnix sylvatica dan Turnix suscitator yang merupakan anggota dari famili Turnicidae. Ducula lacernulata, Collumba livia, dan Geopelia striata dari Famili Collumbidae. Collocalia vukanorum dari famili Appopidae. Spesies Picoides mollucensis dan Dinopium Javanense dari famili Picidae. Picnonotus aurigaster dan Picnonotus goiavier dari famili Pycnononidae. Phylloscopus borealis dan Cisticola exilis dari famili Sylviidae. Aethopygia eximia merupakan anggota dari Nectaridae, Zosterps palpebrosus, Zosterops flavus dan Zosterops everitti dari famili Zosteropidae. Passer montanus dari famili Plocidae, malacopteron cinereum dari Famili Timaliidae, dan Anthus novaeseelandiae dari famili Motacilidae.

Perencanaan kegiatan Birdwatching dapat dilaksanakan sebagai salah satu upaya konservasi dan peningkatan kesadaran masyarakat awam akan pentingnya mengenal dan mencintai burung. Jalur yang bisa digunakan untuk kegiatan pengamatan burung 
(Birdwatching) di desa Ngadas adalah dengan mengikuti jalur setapak di hutan sekunder dan daerah ladang pada pagi dan sore hari, sementara jalur konservasi dibuat berdasarkan lokasi dijumpainya burung-burung yang berada dalam status Endangered dan Near Threathened.

Saran

Saran yang bisa disampaikan berdasarkan analisis yang dilakukan adalah penelitian ini bisa dilanjutkan dengan upaya untuk melaksanakan ekowisata Birdwatching di Desa Ngadas sehingga keberadaan burung di wilayah desa Ngadas bisa dijadikan salah satu daya tarik tersendiri bagi kegiatan wisata di desa Ngadas, selain itu dengan memberikan pendidikan dan pelatihan tentang pengelolaan kegiatan wisata birdwatching bagi masyarakat setempat akan memberikan nilai tambah bagi pelaksanaan kegiatan wisata Birdwatching di desa ngadas ini.

\section{DAFTAR PUSTAKA}

[1]. Ballen, V. B. 1999. Birds of Fragmented Island Persistence in the Forest of Java and Bali. Wageningen University. Netherland

[2]. Burung Indonesia. 2010. Program Burung Indonesia. http://burung.org. Diakses tanggal 2 Juni 2010

[3]. Chettri,N,E.Sharma, and D.C Deb. 2001.Bird Community Structure along a Trekking Corridor of Sikkim Himalaya: a Conservation Perspective. Biological Conservation. 102: 4,11

[4]. Dahlan. 2009. Studi Pemanfaatan Habitat Oleh Cucak Kutilang (Pycnonotus aurigaster Veillot) Di Kebun Raya Bogor. PKM-AI Institut Pertanian Bogor. Bogor

[5]. Dephut.2010. Kemungkinan Meningkatkan Ekowisata. http://www.dephut.go.id. Diakses tanggal 28 April 2010

[6]. Mckinnon, J.1992.Panduan lapangan Pengenalan Burung-burung di Jawa dan Bali. Yogyakarta: Gadjah Mada University Press.

[7]. National Audubon Society.2001.The Sibley Guide to Bird Life and Behavior. Alfred A.knopf. new York

[8]. Peterson. 1980. Burung Pustaka Alam"Life". Tira pustaka. Jakarta.

[9]. Strange, M dan Allen Jeyatajasingan. 1996. A Photographic Guide to the bird of
Peninsular Malaysia and Singapore. Sun Tree Publishing Limited Singapore 